\title{
The Correlation between Occupational Health with Job Performance at Woman Worker with Dual Role
}

\author{
Ariana Sumekar $^{1}$, Soebijanto ${ }^{2}$, Hadi Sutarmanto ${ }^{3}$ \\ ${ }^{1}$ Department of Public Health, School of Health Sciences Wira Husada Yogyakarta, Indonesia \\ ${ }^{2}$ Department of Magister of Occupational Health, Faculty Of Medicine, Universitas Gadjah Mada, Indonesia \\ ${ }^{3}$ Department of Psychology, Faculty of Psychology, Universitas Gadjah Mada, Indonesia
}

\begin{tabular}{l} 
Article Info \\
\hline Article history: \\
Received Nov 21, 2015 \\
Revised Jan 25, 2016 \\
Accepted Feb 27, 2016 \\
\hline
\end{tabular}

\section{Keyword:}

Occupational health

Performance

Woman worker

Work motivation

Workload

\begin{abstract}
Work environment and workload factors in terms of occupational safety and health aspects may lead to health problems that have an impact on decreasing the ability of the workforce to work physically and debilitating mental acuity to think so will degrade performance. Performance degradation is also influenced by the presence of an unbalanced work load and work motivation. The purpose of this research was to know the relationship between occupational health with a performance that is controlled by the workload and motivation of working in a dual role those women workers at PT. Mataram Tunggal Garment Yogyakarta. This study was conducted at PT. Mataram Tunggal Garment Yogyakarta with cross-sectional design. The samples in this study were 86 female workers were taken by simple random sampling. Uses data collected questionnaires and interviews. Data analysis was performed with the Pearson product moment test, whereas the partial correlation analysis and multivariate linear regression with a significance of $\mathrm{p}<0.05$. The Results showed there was a significant relationship between occupational health with a performance that is controlled by the workload and work motivation. The motivation of working has the most effective contribution to performance. While the burden of households does not affect the performance of the woman worker with a double role in PT. Mataram Tunggal Garment Yogyakarta.
\end{abstract}

Copyright $(2016$ Institute of Advanced Engineering and Science. All rights reserved.

\section{Corresponding Author:}

Ariana Sumekar,

Department of Public Health,

School of Health Sciences Wira Husada Yogyakarta,

Jl. Babarsari, Glendongan, Tambak Bayan, Catur Tunggal, Depok, Sleman, Yogyakarta, Indonesia.

Email: ariana_sumekar@yahoo.co.id

\section{INTRODUCTION}

Environmental factors of work and work load in terms of occupational safety and health aspects of work can lead to health problems such as fatigue, accidents, and other health problems [1]. Health problems have an impact on decreasing the ability of the workforce to work physically, weaken the sharpness of thought, as well as decreased alertness and accuracy so that the corresponding labor are prone to accidents. They are actually able to shoulder the workload within a certain boundaries or an optimal workload for someone [2].

Women workers have a dual role as housewives and workers. Both must be implemented properly to achieve workforce healthy, productive work. Conflict in the family was very influential with the behavior and performance of one's work [3]. Changes in the pattern of the occurrence of the labor force in the United States in 1900 shows the number of women working outside the home as much as $21 \%$, in the 1950 increased to $29 \%$ and in 1990 this number increased sharply to reach $63.2 \%$.Changes to working patterns also occur in Australia are characterized by increased participation of women in the workforce became the key 
environmental change organization in Australia. Australia Bureau of Statistics (ABS) in 1996, took note of the participation of women in the workforce by as much as $27 \%$ of the total workforce and $33 \%$ were fulltime workers [4]. Women who work will get some benefits, such as increasing family income, particularly when their salaries are needed, will improve the ability of social status, and confidence [5].

PT. Mataram Tunggal Garment Yogyakarta is a garment company that has an international market orientation. Women workers are required to complete the job with full accuracy, speed, neatness, and must meet the target number in each hour. Attendance rate of workers is a problem that is still high in the garment company. Based on information from the staffing indicates absence of 57 workers by reason of illness as much as $49.1 \%, 42.1 \%$ as much license , and as much as $8.8 \%$ without explanation. Information based on interviews indicate that some workers have motivation to work to increase the family income. Motivation is the driving force of someone to behave, so good to poor performance of someone affected by the motivation of every worker. The problem can be formulated as to how the relationship between occupational health with a performance that is controlled by the workload and work motivation.

\section{RESEARCH METHOD}

This study uses cross-sectional design. The population in this study was women workers in the sewing at PT. Mataram Tunggal Garment Yogyakarta who are married as many as 595 people. Sample is limited to the inclusion criteria : 1) already have children; 2) have worked at least 2 years in the sewing section; 3) willing to respondents, and exclusion criteria : 1) in pregnant condition; 2) has other odd jobs after returning to work. Number of samples was calculated by using the formula Yamane [6] obtained by 86 workers. Sampling technique employed simple random sampling. Tools for data retrieval using microtoise and scales to measure body mass index (BMI), a stopwatch to measure the pulse rate and the questionnaires were made by the researchers consisted of a mild mental disorder questionnaire in the form of stress, work motivation questionnaire, and questionnaires workload. Reliability test results for mental disorders in the form of stress by alpha 0.7258 and 0.7632 alpha motivation to work with. Analysis of the test data using Pearson product moment while the multivariate analysis using partial correlation analysis and linear regression analysis with $95 \%$ confidence intervals $(\alpha=0,05)$.

\section{RESULTS AND ANALYSIS}

Respondents according to the characteristics of the age average is 26-30 year span as many as 19 people (35.8\%), respondents with an average length of 11-15 years working as many as 19 people (35.8\%) and respondents with high school education level as many as 41 people (77.4\%). Women workers in the performance of the low category experienced by the age group 26-30 year low, the performance of many experienced workers with working period at 2-5 years and the level of education of high school.

Statistical test results with partial correlation indicates that there is a significant relationship between health variables (X1) with worker performance (Y) which is controlled by workload (X2) and motivation (X3) of $\mathrm{r}=0.2852(\mathrm{p}=0.042)$.

Regression analysis for occupational health (X1), workload (X2), work motivation (X3) with performance $(\mathrm{Y})$ can be seen that simultaneously there was a significant relationship between occupational health, workload and motivation of working with performance (Freg $=4.389, \mathrm{p}=0.008$ ) and the effective contribution of $21.2 \%$. The motivation of working has the most effective contribution to performance.

The significance of correlation regression obtained the value of $F$ reg $=4,389$ with significance of 0.008 ( $\mathrm{sig}<0.05$ ) thus simultaneously there is a significant relationship between occupational health, workload, performance and motivation of working with women workers who played doubles at PT. Mataram Tunggal Garment Yogyakarta. Variables that have a relationship with the most powerful performance is the motivation of working variables $(\mathrm{sig}=0.005)$.

Results of bivariate analysis with Pearson Product Moment Correlation test is shown that between occupational health performance shows a very low correlation $(\mathrm{r}=0,171)$ and patterned positive which means the better the health of work then the higher performance. Results of statistical tests indicate that there

There is a significant relationship between occupational health and performance $(p=0.222)$. The magnitude of the contribution of health work on performance variables 4,65\%. Between the workload performance indicating a very low relationship $(r=-0,179)$ and a negative meaning patterned increasingly heavy workload then the lower the performance. Based on the results of the statistical analysis are not obtained a significant relationship between workload and performance $(p=0,199)$. The magnitude of the contribution to the variable workload of the performance is $4.22 \%$.

Between the motivation of working with performance demonstrates the relationship low $(r=0,328)$ and patterned positive which means the higher motivation of work then the higher performance. Statistical 
analysis of results indicates that there is a significant relationship between the motivation of working with performance $(\mathrm{p}=0,017)$. The magnitude of the contribution of work motivation on performance variables is $12.3 \%$. Based on the results of the research the average worker has motivation in high category $(58.5 \%)$. Simultaneous donations effectively variable occupational health, workload, and work motivation of $21.2 \%$ whereas $78.8 \%$ were influenced by other factors not examined.

\subsection{Discusion}

The condition of good health is its potential to achieve a good working productivity. Labor is sick or having health problems will experience a decrease in the ability to work physically, thought, or perform a job social development so that his work was reduced [1]. The results showed there was a significant relationship between occupational health performance when the conditions workload and work motivation on women workers in PT. Mataram Tunggal Garment Yogyakarta controlled. If workload and work motivation not controlled there was no significant relationship between occupational health and performance, so that it can be concluded that the workload of women workers and the motivation at PT. Mataram Tunggal Garment Yogyakarta has an impact on performance.

Based on the results of the study found that the motivation of working in a high category of $32.1 \%$. The average worker has a high work motivation then a high-performance, otherwise the average worker has a low work motivations then the having a low performance anyway. The greater the motivation of working more and making labor passionate in performing its work will make workers healthier and fitter [1]. Thus workers looked excited and showed a healthy condition in the work.

In this study there was no significant relationship between workload and performance in female workers in PT. Mataram Tunggal Garment Yogyakarta. Based on the results of the study found the average worker experienced a mild mental disorder in the form of stress in the category is $39.6 \%$. It is influenced by the demands of the task or achievement of the targets set by the company so high that workers vying to achieve the targets that have been set.

Lazarus and launier [7] suggests that when someone feels there is an imbalance between the demands of duty with its resources, then he feels unable to deal with it then it will stress arises. Based on interviews of workers obtained information that workers experience increased working time outside hours of work reach the target set by the company. Arriving at home still must work the household chores and they claimed to have to get up early to prepare her family's needs. Such a condition, they live every day as a routine. This is the factor that caused the workers complained of fatigue and feels less enough time off. A laboring mother in factory, at least will have an effect on to its role within their family. Laboring woman has the reason of that working to represent a requirement or choice. One of them is because of poorness storey, level and unemployment which progressively mount so that contribution mother has to work to assist economics of family [8]. This is possible because the accumulation of fatigue that occurs every day so it can degrade performance. Factors cause the onset of fatigue in the industry varies greatly, to nurture and maintain the health and efficiency of the process of revitalization should be done outside pressure. Refreshment happens especially during the night and sleep time periods of rest and the times stopped working [9].

Although women workers have a dual role, but based on the results of the study showed there was no significant relationship between workloads with performance on the double role of women workers at the PT. Mataram Tunggal Garment Yogyakarta. Thus it can be concluded that a dual role on women workers do not affect on performance. This is because the workers are women--although they are working outside the home it doesn't mean they forget their role and function as in charge of the Affairs of the household chores, so they do not feel impaired its performance with a dual role which they should attend. They keep doing household chores such as cooking, washing, sweeping, and take care of the child. Based on the results of interviews of workers mentioned that the average worker PT. Mataram Tunggal Garment Yogyakarta has the motivation of working to fulfil the needs of economically and life add to earnings. The average is working woman's husband who is working in PT. Mataram Tunggal Garment Yogyakarta work as farmers and laborers. This motivates employees to indicate the best possible performance. The main reason that causes women to work as factory laborers is a matter of economics. They worked in factories to supplement the family income, helping load the husband in the family needs [10].

High work motivation can spur workers to achieve the target. Motivation has three elements, namely, encouragement, needs and goals. The basic core of motivation is the need that has not been fulfilled. When the needs of very high intensity, then attempts the fulfilment of those needs very strong or in other words the motivation that is formed is very high [3]. Financially PT. Mataram Tunggal Garment Yogyakarta has given a fairly high salary, giving incentive match his achievements, give money, as well as overtime gives the other amenities that indirectly support the workers so the workers feel comfortable during work. It can provide motivation to workers. The enactment of the incentive systems are able to make the employees 
motivated to improve its performance for the majority of employees, money still remains a strong motivation to even the most powerful [11].

The motivation of people rely on the strong motive there is weak. Motif means a State within one's self (inner state) that encourage, enable, moving towards the goal of funnelling the behaviour [12]. Motivation is the encouragement of private employees is not coercion from outside [13]. It is becoming a very important factor that should be owned by every worker to be able to perform tasks optimally so that it can be believed would produce a good performance. Research results revealed that motivation has a relationship that is positive and highly significant to the performance [14]. In addition to that motivation is one of the factors that affect height low productivity [15].

In order to be assured the State workforce health and productivity it works optimally, then there needs to be a positive balance between elements: 1) workload; 2) additional expenses resulting from) the work and work environment; 3 ) work capacity [1]. Thus occupational health is a State of the workforce feels safe and comfortable with a health condition and personality, needs and welfare of his life, employee safety when working. Occupational health is part of health science that aims to make labor obtains a perfect health condition either physical, mental and social events, so that it can be taken to a conclusion that the health of the work contains two important elements, namely maintaining the degree of health and maintain the goal to work optimally [16].

There are two main things that determine the productivity of the work ability of workers and others are employee motivation is the driving force towards progress and improvement of a person's job performance [17]. Additionally Elton Mayo emphasized the importance of employee motivation as an essential element of human productivity improvement. In this socio- psychological terms that are nonphysical and non- technical workers are most likely to be the dominant factor in all the activities and level of work productivity [17].

Effective contribution occupational health variables on the performance of $4.65 \%$, variable workload on the performance of $4.22 \%$ and an effective contribution to the performance of work motivation variables at $12.3 \%$, so the effective contribution of variables simultaneously occupational health, workload and motivation employment of $21.2 \%$, while $78.8 \%$ influenced by other factors that were not studied. In addition to the work performance is affected by health workers is also influenced by other factors such as motivation, educational background, employment skills, experience, level of welfare, the appreciation and sanctions and employment [1]. Therefore, health is not the only factor that determines the performance of workers, but health is not possible without good performance can be realized. Other factors not examined in this study were: 1) the work environment, the work environment at PT. Mataram Tunggal Garment that affect performance such as noise, lighting, dust, and work climate, 2) physical fitness, sports cover, and 3) the characteristics of the organization.

\section{CONCLUSION}

There is a significant relationship between occupational health with a performance that is controlled by the workload and motivation of working in a dual role that women workers at PT. Mataram Tunggal Garment Yogyakarta, however if the workload and motivation of work not controlled, there is not significant relationship between occupational health and performance. Simultaneously, there is a significant relationship between occupational health, workload and motivation of working with performance at woman worker with dual role in PT. Mataram Tunggal Garment Yogyakarta and work motivation contributed the largest effective against women workers in the performance of PT. Mataram Tunggal Garment Yogyakarta. Dual roles on women workers do not affect on performance, this is because household chores has become her responsibilities as a wife, additionally supported by a woman worker motivation high.

\section{ACKNOWLEDGEMENTS}

1. Directur of PT. Mataram tunggal Garment Yogyakarta

2. Managing Human Resource PT. Mataram Tunggal Garment Yogyakarta, Mrs. Maria Vitarina, S.Psi

3. Mr. Kismaryono and Mrs. Meita Dwi J, staffs in Human Resource Managemen, PT. Mataram Tunggal Garment.

\section{REFERENCES}

[1] Suma'mur, "Higiene Company and Occupational Health", Sagung Seto, Jakarta, 2009.

[2] Notoatmodjo, S., "Principle of Base Public Health", Rineka Cipta, Jakarta, 2003.

[3] Gitosudarmo, I., Sudita, IN., "Organizational behavior, $1^{\text {st }}$ Edition”, BPFE, Yogyakarta, 2000. 
[4] Cahyaningdyah, D., "Analysis Conflict of Work Family At Woman Worker in Industry Banking", J. Dynamics Management, vol/issue: 1(1), pp. 10-18, 2009.

[5] Abbot, MR., "Masculine \& Feminine, $2^{\text {nd }}$ Edition", Mc Graw Hill, Inc, New York, 1992.

[6] Setiadi, G., "Relation between Trouble Hearing Because Presentation Noise with Behavior Usage of Appliance Protector X' Self At Employees in Weave Room PT. Cambrics Primissima Yogyakarta", Thesis, do not Published, Universitas Gadjah Mada, 2009.

[7] Sutherland, VJ., Cooper, CL., "Models of Job Stress, In: Thomas, J.C., Hersen, editors, Handbook of Mental Health in The Workplace", California, Sage Publications, pp. 61-70, 2002.

[8] Oemar, R., Novita, A., "Take Care Pattern in Health of Child at Mother Labour Factory", Journals of Public Health, vol/issue: 11(1), Semarang State University, 2015.

[9] Grandjean, "Fitting The Task to The Man, $4^{\text {th }}$ Edition", A Text Book Occupational Ergonomics, Philadelphia, New York, London, 1991.

[10] Wijayanti, DM., "Shackle Poorness of Woman Labour at Cigarette Factory", J. Community, vol/issue: 2(2), pp. 8493, 2010.

[11] Handoko, M., "Motivation Locomotion Behaviour", Kanisius, Yogyakarta, 1992.

[12] Kontz, S., "Work Design, Industrial Ergonomics, $3^{\text {rd }}$ ed”, Publishing Horizons, Washington, OH, 1990.

[13] Rahmawati, R., "Influence Motivate To Work Productivity Employees PT. National Capital Madani Banjarmasin", J. Management And Accountancy, vol/issue: 11(1), 2010.

[14] Le Pine, Jeffrey A., Marcie A., "Challenge and Hindrance Stress, Relationship With Exhaustion, Motivation to Learn, and Learning Performance”, J. App Psychology, vol/issue: 89(5), 2004.

[15] Tarwaka, "Ergonomi Bases Knowledge of Ergonomi and Application in Work place", Harapan Offset, Surakarta, 2011.

[16] Husni, L., "Introductory Law of Labour Indonesia", Raja Grafindo Persada, Jakarta, 2005.

[17] Wignjosoebroto, S., "Ergonomi Motion and Time Study", Guna Widya, Surabaya, 2008. 